\title{
Morphometric Analysis for the Assessment of Relative Tectonic Activity in Evia Island, Greece
}

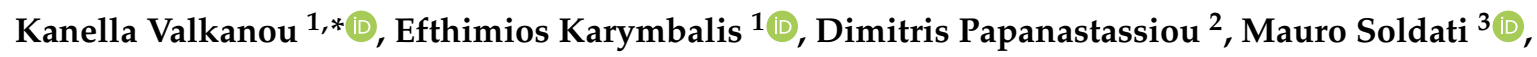 \\ Christos Chalkias ${ }^{1}$ and Kalliopi Gaki-Papanastassiou ${ }^{4}$ \\ 1 Department of Geography, Harokopio University, 70 El. Venizelou Str., GR-17671 Athens, Greece; \\ karymbalis@hua.gr (E.K.); xalkias@hua.gr (C.C.) \\ 2 Institute of Geodynamics, National Observatory of Athens, GR-11810 Athens, Greece; d.papan@noa.gr \\ 3 Department of Chemical and Geological Sciences, University of Modena and Reggio Emilia, \\ Via G. Campi 103, 41125 Modena, Italy; mauro.soldati@unimore.it \\ 4 Department of Geography and Climatology, Faulty of Geology and Geoenvironment, University of Athens, \\ GR-15784 Athens, Greece; gaki@geol.uoa.gr \\ * Correspondence: elnel@otenet.gr
}

Received: 17 June 2020; Accepted: 7 July 2020; Published: 9 July 2020

\begin{abstract}
The aim of this study is to evaluate the relative tectonic activity in the north part of the Evia Island, located in Central Greece, and to investigate the contribution of neotectonic processes in the development of the fluvial landscape. Five morphometric parameters, including Drainage Basin Slope $\left(\mathrm{S}_{\mathrm{b}}\right)$, Hypsometric Integral $\left(\mathrm{H}_{\mathrm{i}}\right)$, Asymmetry Factor $\left(\mathrm{A}_{\mathrm{f}}\right)$, Relief Ratio $\left(\mathrm{R}_{\mathrm{h}}\right)$, and Melton's Ruggedness Number (M), were estimated for a total of 189 drainage basins. The catchments were classified into two groups, according to the estimated values of each morphometric parameter, and maps showing their spatial distribution were produced. The combination of the calculated morphometric parameters led to a new single integrated Index of relative tectonic activity (named Irta). Following this indexing, the basins were characterized as of low, moderate, or high relative tectonic activity. The quantitative analysis showed that the development of the present drainage systems and the geometry of the basins of the study area have been influenced by the tectonic uplift caused by the activity of two NW-SE trending offshore active normal fault systems: the north Gulf of Evia fault zone (Kandili-Telethrion) and the Aegean Sea fault zone (Dirfis), respectively. The spatial distribution of the values of the new integrated index Irta showed significant differences among the drainage basins that reflect differences in relative tectonic activity related to their location with regard to the normal fault systems of the study area.
\end{abstract}

Keywords: drainage systems; geomorphology; active tectonics; morphometric indices; Evia Island; Greece

\section{Introduction}

Landscapes in tectonically active areas result from a complex interaction of the effects of crustal blocks' motion and surface processes, such as erosion and deposition. The interplay between tectonics, bedrock lithology, and climatic conditions is responsible for landscape evolution [1]. Hence, landscape morphology can provide insights into the interactions of surface processes and tectonic activity [2]. Drainage systems have a crucial role in the whole process, since, on one hand, are involved in the evolutionary processes of the Earth's surface morphology and, on the other hand, are affected and reflect the tectonic conditions $[1,3,4]$.

The landscapes of Greece reflect in many ways the influence of recent tectonics. Morphotectonics, including the quantitative study of drainage networks and corresponding catchments, can contribute 
to our knowledge on active normal fault evolution in places with poor historical earthquake data [5]. Such studies incorporate quantitative measurements that allow for geomorphologists to calculate morphometric parameters that may be useful in detecting anomalies in the fluvial systems, produced by local changes that result from tectonic uplift or subsidence. Such approaches provide a quantitative method for the evaluation of the influence of active tectonics on landscape morphology and drainage evolution in a specific area $[2,6]$.

For the identification of the relative tectonic activity of an area, a single quantitative analysis can be made, but the results are more meaningful if more indices are applied [2,7]. Several studies focus on a specific index for an area [8,9], but many others evaluate the relative tectonic activity in the wider region and with the use of multiple quantitative morphometric parameters (e.g., [10-15]). Recently, the quantification of drainage basins' topography through the combination of multiple morphometric variables, in order to produce a single index that can be used to characterize relative tectonic activity, is a common approach in studies of active tectonics (e.g., [7,10,16-18]).

This paper investigates the role of neotectonic processes in the evolution of the landscape of the north part of the Evia Island, located in Central Greece, through the calculation of five morphometric parameters describing 189 drainage basins. These individual morphometric variables were combined into a new proposed single integrated Index of relative tectonic activity (named Irta) that was used to evaluate the relative rates of active tectonics.

The north part of the Evia Island is considered as a tectonically active area, as it is located between the north Gulf of Evia, which is among the most active structural features of Greece, [19] and the North Aegean Sea, which is a trans-tensional deformation zone affected by the western branches of the north Anatolian fault system [20]. The influence of tectonic processes on the landscape evolution of the island is obvious and, thus, the quantitative analysis with the use of multiple morphometric parameters can lead to the assessment of the relative tectonic activity in the study area.

\section{Study Area}

The north part of the Evia Island forms a strip of land between the Aegean Sea to the northeast and the north Gulf of Evia to the southwest. To the north the island is separated from the central mainland of Greece by the Oreos-Trikeri Straits. The topography of the area can be described as a succession of mountain ranges and low elevation plains (Figure 1).

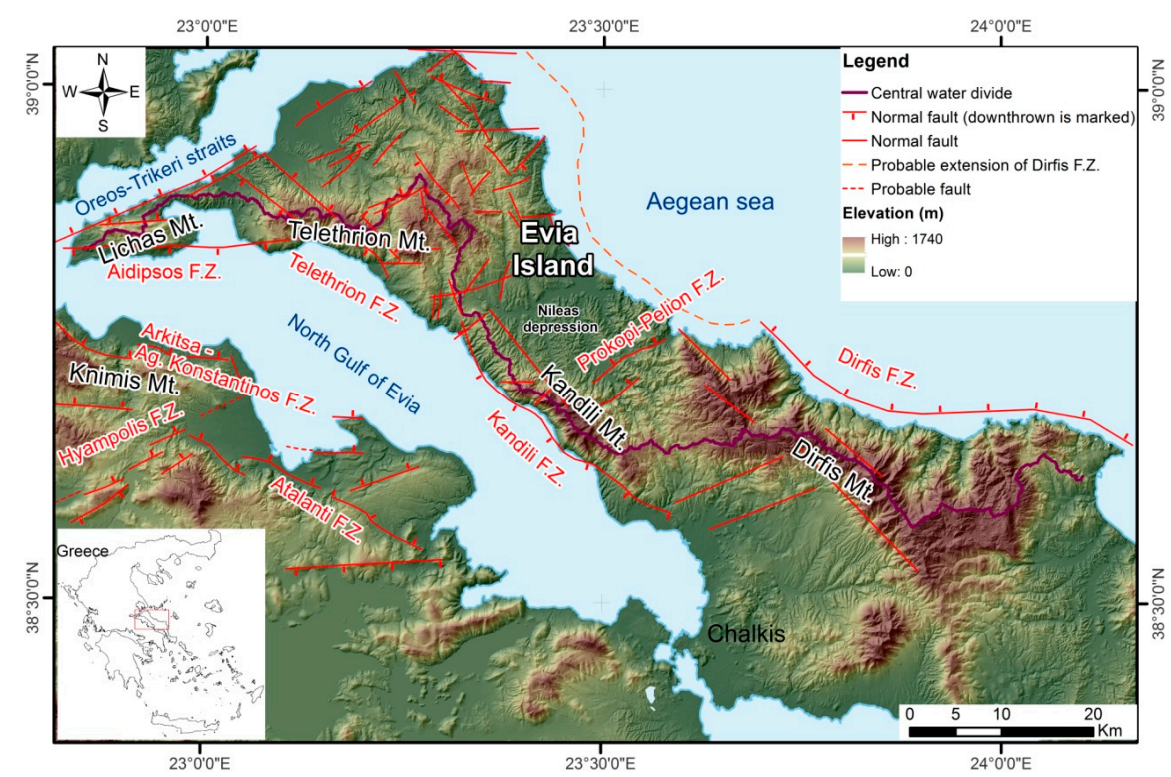

Figure 1. Digital Elevation Model (DEM) of the broader area of the north part of the Evia Island. The main central water divide as well as the main fault zones are also depicted (fault zones are based on several studies and databases [21-30]). 
The study area consists of Alpine and Post-Alpine geological formations (Figure 2). Alpine formations belong to the Sub-Pelagonian geotectonic zone of the Internal Hellenides and they include carbonate rocks of Triassic-Jurassic age, the ophiolite complex of Upper Jurassic-Lower Cretaceous age and the Upper Jurassic-Lower Cretaceous schist-chert formation [31]. During the period of Upper Jurassic-Lower Cretaceous the zone emerged, Fe-Ni (iron-nickel) deposits were formed and were subsequently covered by the Middle-Upper Cretaceous tectonic nappe that consists of Upper Cretaceous (transgressive) limestone and ultrabasic rocks [32]. The Post-Alpine formations consist of fluvio-lacustrine deposits of Upper Miocene age and fluvio-lacustrine deposits of Pleistocene age. At the mouth of the rivers and along the major central channels of the drainage networks recent Holocene alluvial deposits occur.

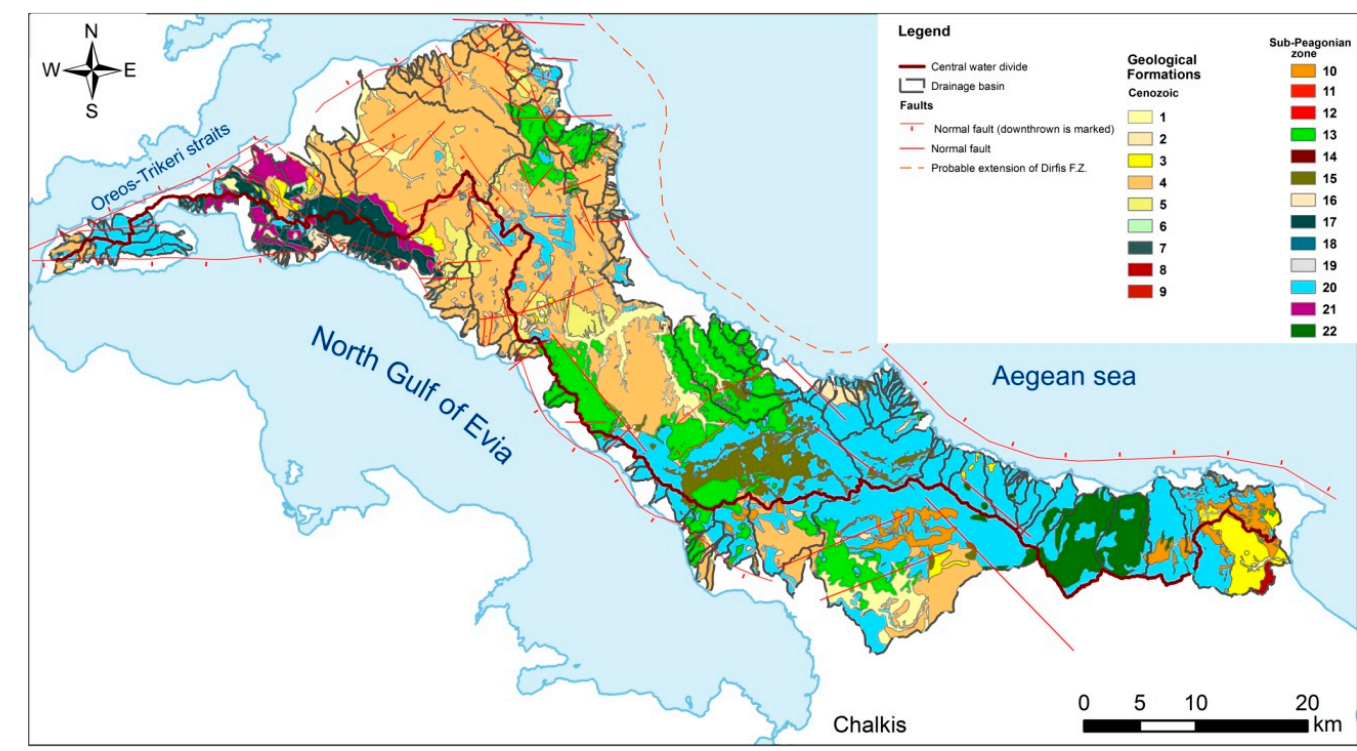

Figure 2. Simplified geological map and outline of the drainage basins of the study area based on the geological map of Greece published by the Institute of Geology and Mineral Exploration of Greece (IGME) [33] (1: alluvial deposits (Quaternary), 2: recent talus cones (Quaternary), 3: Neogene sediments (Neogene), 4: marl (Neogene), 5: conglomerate (Neogene), 6: olistolith (Neogene), 7: andesite (Neogene), 8: lavas (Neogene), 9: magnesite deposits (Paleogene), 10: flysch (Upper Cretaceous), 11: iron-nickel ore (Upper Cretaceous), 12: bauxite (Upper Cretaceous), 13: ophiolite (Upper Jurassic-Lower Cretaceous), 14: chert (Upper Jurassic-Lower Cretaceous), 15: schist-chert (Upper Jurassic-Lower Cretaceous), 16: talus cones (Middle Triassic), 17: greywacke (Triassic), 18: diabase (Meosozoic), 19: tuff (Permian), 20: limestone, dolomite (Permian, Triassic-Cretaceous), 21: gneiss (Pre-Carboniferous), and 22: schist (Paleozoic)).

The north Gulf of Evia is among the most active structural features of Greece where faulting is localized today $[27,34]$. Neotectonic and stratigraphic studies of the Neogene and Quaternary formations of the study area $[23,27]$ indicate the existence of traces of two, NE-SW and NNW-SSE directed, Miocene-Pliocene extensional tectonic phases that are responsible for the normal faults' activity. A third Pliocene-Pleistocene phase associated with strike-slip faults (N100-120 ), with main counter clockwise movement, has been also recognized $[23,27]$. The N-S extension strain rates across the central part of the Evia Island, accommodated by the coastal fault system, equals 53 ns/yr, whereas the extension drops about $50 \%$ further southeast onshore of the Evia Island [35].

Drainage in the broader region of central Greece is controlled by fault segmentation and footwall lithology [22]. The fault system of the northern part of the Evia Island corresponds to two major offshore antithetic normal fault zones, having a NW-SE strike, which bound the mountainous relief and separate the land from the north Gulf of Evia and the Aegean Sea. These are the Kandili-Telethrion fault zone to the west dipping to SW, and the Dirfis fault zone to the east dipping to the NE (Figure 1). Roberts and Jackson [22] suggest that the Dirfis fault, which runs along the northern side of Dirfis Mountain, is more active or it has larger displacement and continues offshore further to the north, following the $-200 \mathrm{~m}$ 
isobath, with characteristics that are indicative of relatively lower tectonic activity. As regards the probable offshore continuation of the Dirfis fault zone, according to Palyvos et al. (2006), there is a fault zone (Prokopi-Pelion) at the SE flank of the Nileas Dipression that could act as a barrier to the propagation of the Dirfis fault zone, just like the cases of the Atalanti and Hyampolis fault zones on the opposite mainland [36]. The offshore active normal faults along the two coasts of the island seem to be responsible for the evolution of the landscape. The pattern of drainage systems and specific landforms of the north Evia Island, such as coastal fans, facets, terraces, and uplifted marine notches suggest recent uplift [37-39]. The main faults of the study area, recognized by various authors [21-30], as well as the central water divide of the north part of the island, are shown in Figure 1. No strong instrumental earthquakes have occurred in the region, but several historic events are recorded [40]. In particular, the north Gulf of Evia seems to be almost free of strong earthquakes for the period 1900-2013 and seismic energy is released in the form of earthquake swarms [41]. According to the Institute of Geodynamics of the National Observatory of Athens two earthquakes with local magnitudes $\left(\mathrm{M}_{\mathrm{L}}\right) 5.2$ happened on 17 November 2014, $25.6 \mathrm{~km}$ and $26.2 \mathrm{~km}$ NW of Chalkis, respectively, whereas almost one year later, on 9 June 2015, another strong earthquake of 5.3 magnitude occurred $25.2 \mathrm{~km}$ NW of Chalkis.

\section{Materials and Methods}

\subsection{Data Collection}

A major part of the morphometric analysis carried out within this research is based on the spatial geo-database that was designed and implemented for the study area. In the first phase, topographic maps published by the Hellenic Military Geographical Service (HMGS) and geological maps published by the Institute of Geology and Mineral Exploration of Greece (IGME) were collected in analogue form at 1:50,000 scale. Then maps were scanned and georeferenced to a common coordinate system (Hellenic Geodetic Reference System 1987-HGRS87). The primary GIS layers of the geo-database, derived from the above-mentioned maps, include the coastline, contour lines at $20 \mathrm{~m}$ intervals, elevation points, drainage networks, water divides, geological formations, and faults. The use of ArcGIS and several extensions (e.g., Spatial Analyst) contributed to the extraction of secondary thematic layers (e.g., the DEM with $25 \times 25 \mathrm{~m}$ cell size, the hillshade, etc.) from the primary layers. Many published papers and databases [21-30], along with DEM analysis and interpretation of Google Earth images, were used to recognize and map the main faults. Field control was necessary to correct and validate the preliminary map of the main fault zones that was drawn for the study area.

\subsection{Geomorphic Indices}

In order to better understand the landscape evolution and determine the role of active tectonics, five morphometric parameters-including Drainage Basin Slope $\left(\mathrm{S}_{\mathrm{b}}\right)$, Hypsometric Integral $\left(\mathrm{H}_{\mathrm{i}}\right)$, Asymmetry Factor $\left(A_{f}\right)$, Relief Ratio $\left(R_{h}\right)$, and Melton's Ruggedness Number $(M)$-were calculated for a total of 189 catchments. Among these morphometric parameters, the Hypsometric Integral $\left(\mathrm{H}_{\mathrm{i}}\right)$ and the Asymmetry Factor $\left(\mathrm{A}_{\mathrm{f}}\right)$ are the most commonly used and they are considered as basic reconnaissance tools to identify tectonic deformation [2]. For each of these indices the catchments of the study area were categorized into two classes according to the estimated values. Class 1 includes basins of low values for a given parameter, related to low tectonic activity, while Class 2 consists of basins of high values of the parameter and corresponds to areas of high tectonic activity. In addition to the calculation of the descriptive statistics for the indices of all the basins, a series of maps showing the spatial distribution of the values of these morphometric indices in the study area were drawn.

\subsubsection{Drainage Basin Slope $\left(\mathrm{S}_{\mathrm{b}}\right)$}

The Drainage Basin Slope $\left(S_{b}\right)$, was obtained using the following equation:

$$
\mathrm{S}_{\mathrm{b}}=\left(\mathrm{e} * \Sigma \mathrm{L}_{\mathrm{c}} / \mathrm{A}_{\mathrm{b}}\right) * 100
$$


where $=$ contour interval $(20 \mathrm{~m}), \mathrm{L}_{c}=$ total length of $20 \mathrm{~m}$ contour lines within the basin, and $\mathrm{A}_{\mathrm{b}}=$ basin area.

In rapidly uplifting areas river incision is the main fluvial process resulting in steep catchments, which become progressively less steep with time after cessation of uplift [3]. Drainage basins with steep slopes usually develop on the side abutting the fault scarp, adjacent to the fault [1]. Thus, high $S_{b}$ values indicate higher tectonic activity.

\subsubsection{Hypsometric Integral $\left(\mathrm{H}_{\mathrm{i}}\right)$}

The Hypsometric Integral $\left(\mathrm{H}_{\mathrm{i}}\right)$ describes the distribution of elevation of a given area of a landscape [42]. It is generally derived for a specific catchment and it is an independent of the catchment area index. It was obtained using the equation $[2,43,44]$ :

$$
\mathrm{H}_{\mathrm{i}}=\left(\mathrm{H}_{\text {mean }}-\mathrm{H}_{\min }\right) /\left(\mathrm{H}_{\max }-\mathrm{H}_{\min }\right) * 100
$$

where $\mathrm{H}_{\text {mean }}=$ mean elevation of the basin, $\mathrm{H}_{\min }=$ elevation of the basin mouth, and $\mathrm{H}_{\max }=$ elevation of the highest point of the basin.

$\mathrm{H}_{\mathrm{i}}$ characterizes the shape of the hypsometric curve for a drainage basin and it is a useful index for the distinction between tectonically active and non-active areas [45]. $\mathrm{H}_{\mathrm{i}}$ is defined as the area below the hypsometric curve and, thus, expresses the volume of a catchment that has not been eroded. In general, high values $(>50)$ indicate high topography, relative to the mean, and correspond to convex hypsometric curves, intermediate values (40-50) tend to represent more concave-convex curves or straight lines, and lower values $(<40)$ tend to have concave shapes [2]. High values generally mean that not as much of the uplands have been eroded, and may suggest a younger landscape, possibly produced by active tectonics, whereas low values are related to older landscapes that have been more eroded and less impacted by recent active tectonics.

\subsubsection{Asymmetry Factor $\left(\mathrm{A}_{\mathrm{f}}\right)$}

The Asymmetry Factor $\left(A_{f}\right)$ is a way to evaluate the existence of tectonic tilting at the scale of a catchment [2], and it is defined as:

$$
\mathrm{A}_{\mathrm{f}}=100 *\left(\mathrm{~A}_{\mathrm{r}} / \mathrm{A}_{\mathrm{t}}\right)
$$

where $A_{r}=$ area of the basin to the right (facing downstream) of the trunk stream and $A_{t}=$ total area of the drainage basin.

If a catchment has developed under stable conditions with little or no tilting, the $\mathrm{A}_{\mathrm{f}}$ factor is close to 50 . Values above or below 50 show tilting either from active tectonics or differential erosion due to lithological differences within the catchment.

\subsubsection{Relief Ratio $\left(R_{h}\right)$}

Relief ratio $\left(R_{h}\right)$ is among the parameters widely accepted as an effective measure of gradient aspects of a catchment [46]. It is a measure of the overall gradient across a catchment given by the formula [47]:

$$
\mathrm{R}_{\mathrm{h}}=\mathrm{H} / \mathrm{L}
$$

where $\mathrm{H}=$ the basin relief that is the difference in height between the highest and lowest points in the basin and $\mathrm{L}=$ the basin length that is the horizontal distance along the longest dimension of the basin parallel to the main stream line.

Catchments of high $R_{h}$ values are usually associated with areas of high tectonic uplift [48]. 


\subsubsection{Melton's Ruggedness Number (M)}

The Melton's Ruggedness Number (M) is a slope index that provides spatialized representation of relief roughness within the catchment [49]. It was estimated using the formula:

$$
M=R_{b} * A_{b}-0.5
$$

where $R_{b}=$ basin relief (the difference in height between the highest and lowest points in the catchment) and $A_{b}=$ total area of the basin.

High $\mathrm{M}$ values correspond to basins with rough relief possibly affected by tectonic uplift, whereas low values usually indicate tectonic stability or slow rates of uplift.

\subsubsection{Index of Relative Tectonic Activity (Irta)}

In order to make the evaluation of the relative tectonic activity in the study area more accurate, apart from the individual evaluation of each one of the individual morphometric parameters, the five calculated variables were combined and the average of their class number ( 1 or 2 ) yielded a new integrated index named "Index of relative tectonic activity" (Irta), which is deduced from the formula:

$$
\operatorname{Irta}=\left(S_{b}+H_{i}+A_{f}+R_{h}+M\right) / 5
$$

where $S_{b}=$ Drainage Basin Slope, $H_{i}=$ Hypsometric Integral, $A_{f}=$ Asymmetry Factor, $R_{h}=$ Relief Ratio, and M = Melton's Ruggedness Number.

The drainage basins were classified according to the new index values into three classes of low (1), moderate (2), and high (3) relative tectonic activity. A map depicting the spatial distribution of the values of this new index was constructed in order to draw conclusions regarding the tectonic pattern of the study area.

In an attempt to investigate the influence of the bedrock lithology on the shape and the slope of the catchments, the geological formations cropping out in the catchments were grouped into four classes based on their resistance to erosion [50]. The contribution of each one of the four main lithological types to the area of each basin was also estimated and its correlation with the values of the morphometric indices was detected.

\section{Results}

\subsection{Morphometric Analysis}

\subsubsection{Drainage Basin Slope $\left(\mathrm{S}_{\mathrm{b}}\right)$}

$\mathrm{S}_{\mathrm{b}}$ values for the catchments of the study area vary from 15.2 to $74.6 \%$. The basins were grouped into two classes: class $1, \mathrm{~S}_{\mathrm{b}} \leq 41.88 \%$ and class $2, \mathrm{~S}_{\mathrm{b}}>41.88 \%$ (41.88 is the mean value of the total of the 189 catchments).

Figure 3a shows the spatial distribution of this variable. Steeper catchments of high $S_{b}$ values, indicative of relatively higher tectonic uplift, are located on the footwalls of Dirfis, Kandili, Telethrion, and Aidipsos normal faults. Some basins of high slope in comparison to their adjacent ones are concentrated at the northeastern part of the island. These high slope values could be related to the lithology, since the area is dominated by highly resistant to erosion lithotypes that tend to form steep slopes. Steep catchments could be also the result of local active and/or probably active faults.

\subsubsection{Hypsometric Integral $\left(\mathrm{H}_{\mathrm{i}}\right)$}

$\mathrm{H}_{\mathrm{i}}$ values range from 13.693 to 68.076 and the mean value is equal to 49.314 . Hi values were grouped into two classes: the class 1 includes catchments with $\mathrm{H}_{\mathrm{i}}<50$ while class 2 consists of basins with $\mathrm{H}_{\mathrm{i}} \geq 50$. 
The spatial distribution of the $\mathrm{H}_{\mathrm{i}}$ values for the study area is shown in Figure 3b. High topography catchments are located on the footwall of the major active fault zones. However, there are also some basins of high $\mathrm{H}_{\mathrm{i}}$ values in the northeast part of the island, indicating possible activity of several local faults of this area. Because there is not a direct relationship between $\mathrm{H}_{\mathrm{i}}$ index and active tectonics [7], the high values in this area could be attributed to the influence of the highly resistant to erosion lithotypes outcropping in this part of the study area.

\subsubsection{Asymmetry Factor $\left(\mathrm{A}_{\mathrm{f}}\right)$}

$A_{f}$ values for the basins of the study area vary from 15.477 to 87.221 and the mean value is 48.346 . For evaluating the relative active tectonics, the absolute difference is what matters. Hence, the values were grouped into two classes: class 1, $45.5<\mathrm{A}_{\mathrm{f}}<55.5$ and class $2, \mathrm{~A}_{\mathrm{f}} \geq 55.5$ and $\mathrm{A}_{\mathrm{f}} \leq 45.5$.

As regards the spatial distribution, almost all of the basins are characterized by a tilting, with only a few showing a stable setting (Figure 3c). It is obvious that the existence of major active fault zones on both sides of the north part of the Evia Island is responsible for this situation. However, some basins between the fault segments of Kandili and Telethrion as well as at the northwestern termination of the Dirfis fault seem to be more stable. The same is observed for some catchments at the northern part of the island.

\subsubsection{Relief Ratio $\left(\mathrm{R}_{\mathrm{h}}\right)$}

$R_{h}$ values for the drainage basins of the north part of the Evia Island range between 0.045 and 0.630 . The catchments were grouped into two classes: class 1 includes basins with $R_{h} \leq 0.22$ and class 2 includes basins with $R_{h}>0.22$ ( 0.22 is the mean value of the total 189 basins). Figure 4 a depicts the spatial distribution of the $R_{h}$ values for the study area. As it was expected, the spatial distribution of this parameter is similar to the geographic distribution of $S_{b}$ with basins of high values located on the uplifting blocks of the main faults. In specific high values appear at the footwalls of the southeastern segment of the Kandili fault zone as well as at the northwestern segment of the Dirfis fault. High $R_{h}$ values are also observed at the catchments of the drainage networks that drain the uplifting block of the Telethrion fault zone. These fault segments seem to be the most recent and most active ones.

\subsubsection{Melton's Ruggedness Number (M)}

In the study area, $\mathrm{M}$ ranges from 0.068 to 1.377 . The basins of the study area were grouped into two classes according to the values of this parameter with Class 1 having the basins with $\mathrm{M} \leq 0.459$ and Class 2 including catchments with $M>0.459$ ( 0.459 is the mean value of the total of the 189 basins). Figure $4 \mathrm{~b}$ presents the $\mathrm{M}$ spatial distribution map. It follows the pattern of the other morphometric indices, clearly showing the development of rough basins on the uplifting blocks of the main faults.

\subsubsection{Index of Relative Tectonic Activity (Irta)}

The values of Irta were divided into three classes that describe the degree of relative tectonic activity: Class $1(1 \leq$ Irta $\leq 1.2)$ characterizes basins of low tectonic activity, Class $2(1.2<$ Irta $\leq 1.6)$ includes catchments of moderate tectonic activity and Class $3(1.6<$ Irta $\leq 2)$ consists of basins that are affected by high tectonic activity. Figure $4 \mathrm{c}$ shows the results of the above classification of the drainage basins. For the study area, which covers $1531.92 \mathrm{~km}^{2}$, the analysis has shown that about $68 \%$ belongs to Class 1, around $23 \%$ belongs to Class 2, and $9 \%$ belongs to the Class 3 . The spatial distribution of the values of this new index seems to reflect the tectonic pattern of the study area. The morphology of the uplifting blocks of the Telethrion fault segment, the southeastern segment of the Kandili fault as well as of the northwestern segment of the Dirfis fault are affected by high relative tectonic activity. 


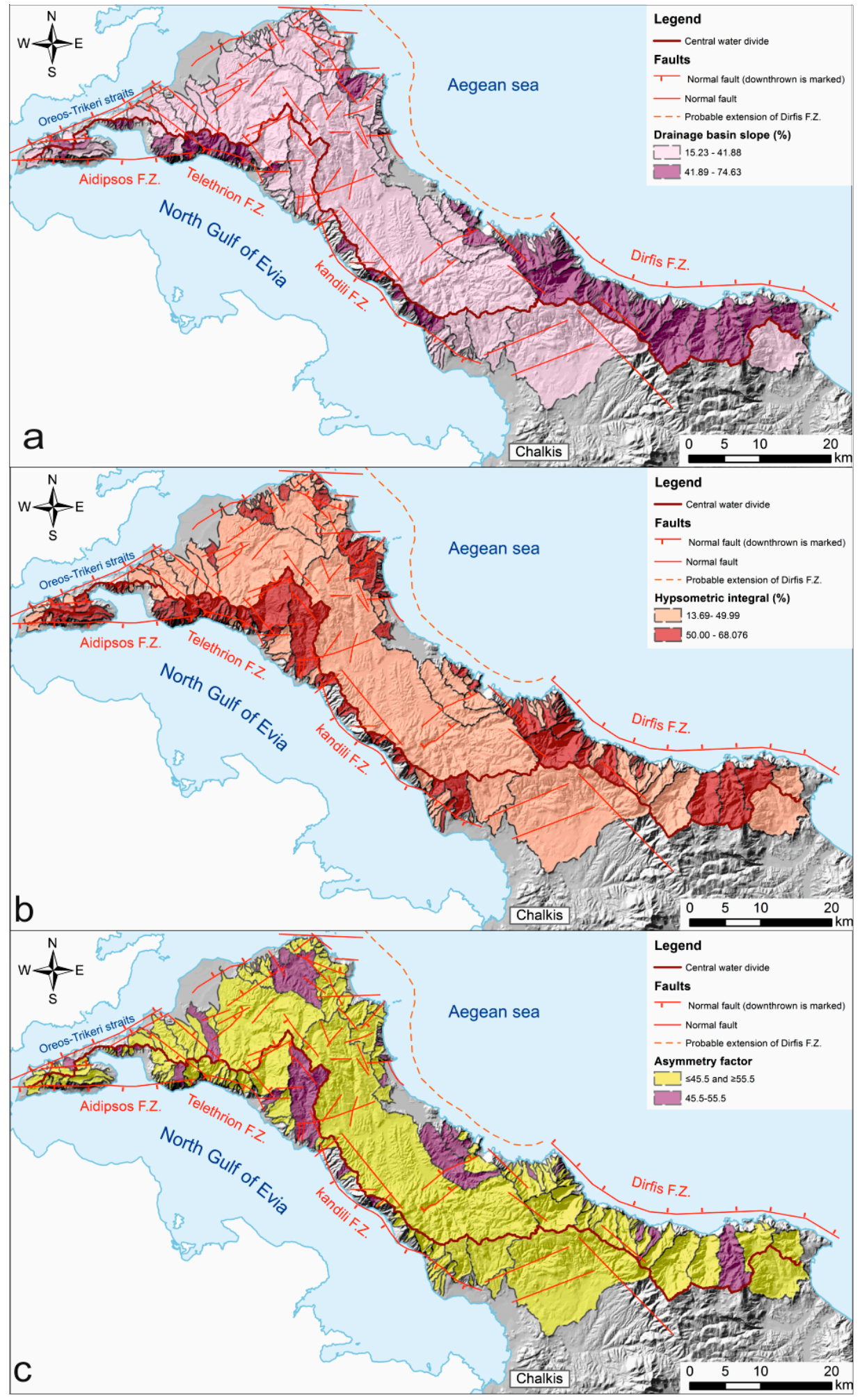

Figure 3. Spatial distribution of (a) Drainage Basin Slope, $\left(\mathrm{S}_{\mathrm{b}}\right)(\mathbf{b})$ Hypsometric Integral $\left(\mathrm{H}_{\mathrm{i}}\right)$, and (c) Asymmetry Factor $\left(\mathrm{A}_{\mathrm{f}}\right)$. 


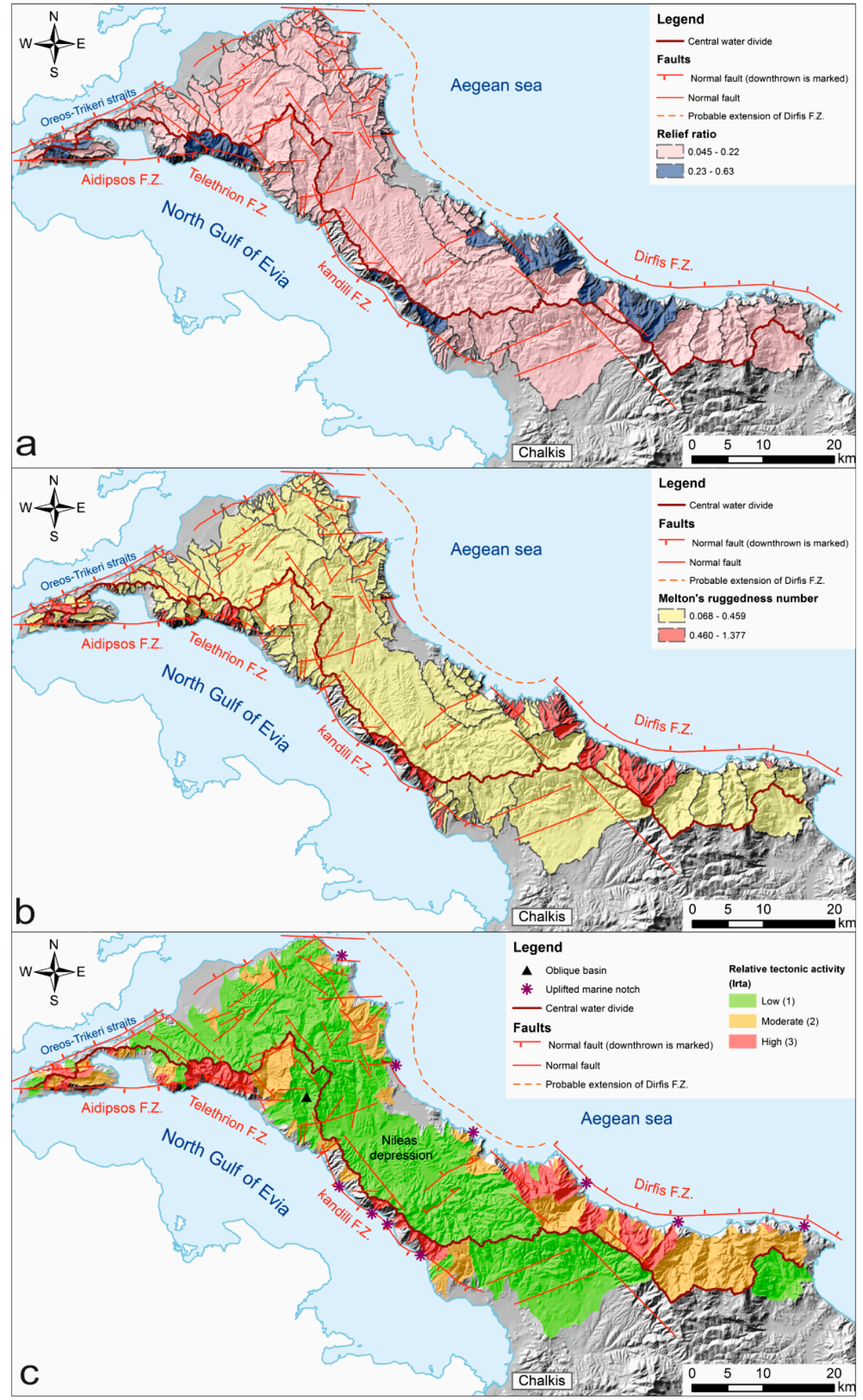

Figure 4. Spatial distribution of (a) Relief Ratio $\left(R_{h}\right)$, (b) Melton's Ruggedness Number $(M)$, and (c) the proposed integrated index Irta, which takes into account the above five morphometric parameters and divides the landscape into three classes of relative tectonic activity; sites of uplifted marine notches (asterisks) are based on Stiros et al. [37]. 


\subsection{The Role of Bedrock Lithology and Surface Deposits}

The geological formations and surficial deposits cropping out in the study area were grouped into four classes based on their resistance to erosion in order to investigate the influence of the lithological types on the shape of the drainage basins [50]. The first group includes surface deposits as alluvial sediments, recent talus cones and scree, and semi consolidated talus cones. The second group of soft—easily erodible geological formations includes marls, sandstones, schists-cherts, and travertines. The third rock group is characterized as of medium resistance to erosion and consists of schists and phyllites, while the fourth group includes very resistant, hard to erode, formations, such as limestone, dolomites, greywackes, consolidated conglomerates, ophiolites, peridotites, and quartzites (Figure 5).

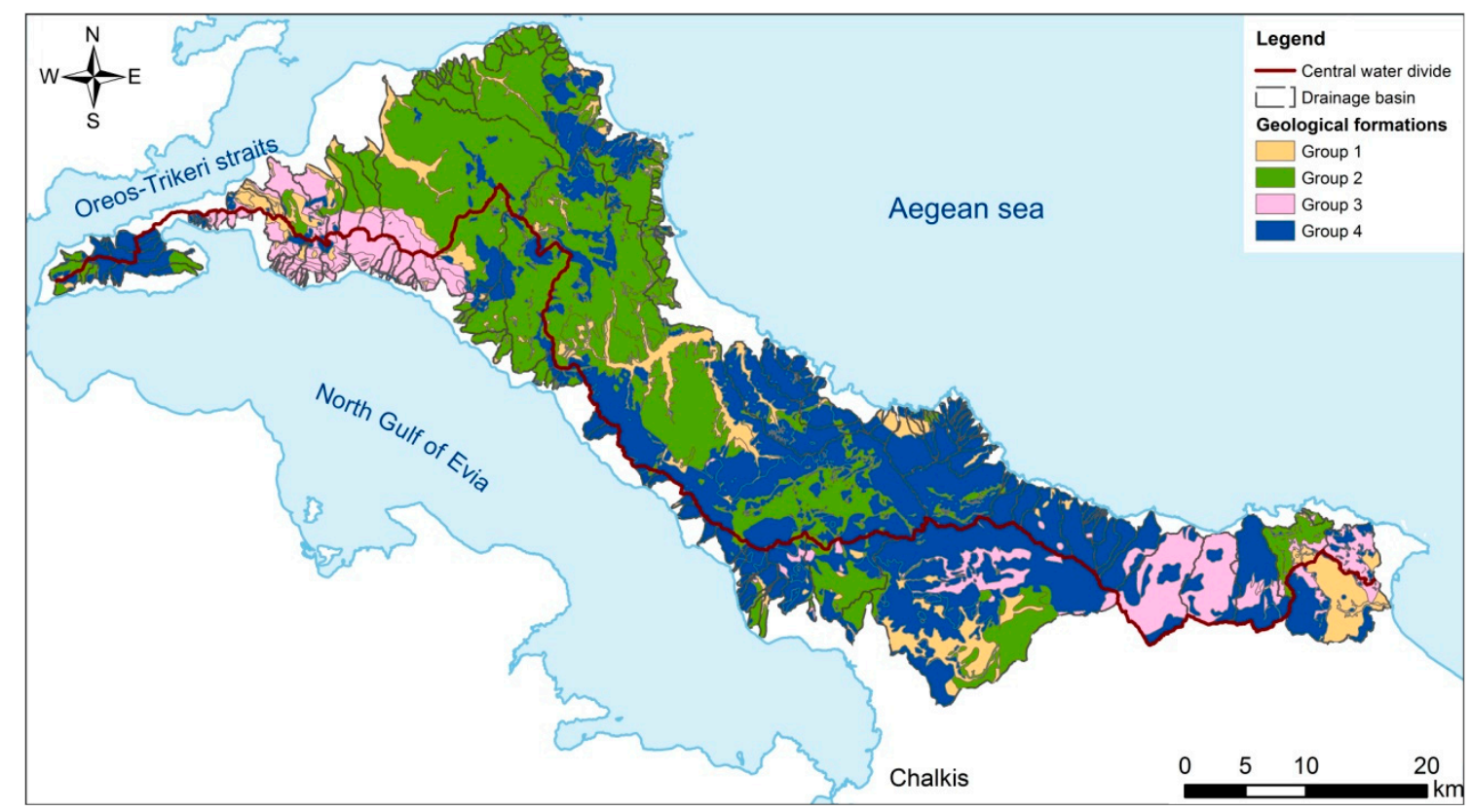

Figure 5. Simplified lithotechnical map of the study area based on the geotechnical map of Greece [33] (Group 1: surface deposits such as alluvial deposits, recent talus cones and scree and semi consolidated talus cones; Group 2: soft geological formations including marls, sandstones, schists-cherts, and travertines; Group 3: formations of medium resistance consisting of schists and phyllites; and, Group 4: very resistant, hard to erode, formations, including limestone, dolomites, greywackes, consolidated conglomerates, ophiolites, peridotites, and quartzites).

The relative distribution of each one of the four main lithological types in the area of each basin was estimated as percentage of the total basin area. An attempt was made to investigate the relationships between the values of the morphometric parameters and the dominant type of lithology, but not significant correlations were found (correlation coefficients vary from -0.05 to 0.1 ). The role of the bedrock control on the geomorphic characteristics of the investigated drainage basins is not clear, probably because of the complexity of the system since most of the basins consist of many formations showing different resistance to erosion. However, according to Goldsworthy and Jackson [5], locally there are clear differences in morphology between places where footwalls are composed of resistant, relatively soft, or weak to erosion terrains.

\section{Discussion}

This study tried to recognize the influence of the tectonics on the drainage systems of the north part of the Evia Island with the use of morphometric parameters that can be easily computed. Additionally, an attempt was made to draw conclusions about the influence of the already mapped main faults, as well as the probable ones, on the evolution of the landscape. 
The topographic and drainage polarity change in the study area has been discussed in detail by Leeder and Jackson [51]. The calculated new index Irta (derived from the combination of five individual morphometric parameters) shows a similarity of low relative tectonic activity for the back-tilted basins of the Dirfis fault zone as well as for the basins that are located between the middle two segments of the Kandili-Telethrion fault zone. All the other basins abutting the footwall are small, steep and rough showing moderate to high relative tectonic activity. The Nileas graben, which acts as an extensive drainage eroding the Neogene deposits, although it seems to be a basin of low tectonic activity; it is influenced by many faults, beside main ones [28]. This graben structure is a major feature that needs to be analyzed in detail. Because of the easily erodible lithology, erosion and uplift equalize each other, giving in this way a result of low tectonic activity.

The north Gulf of Evia is a region that is characterized by the absence of recent surface rupturing events and fault segment boundaries are difficult to be identified. The offset or step over between fault segments can provide enhanced opportunities for drainage growth and, in such cases, the drainage network extends back obliquely behind small basins of the footwall [51]. This is the case of the network that drains the area between the southern segments of the Kandili fault zone (marked with a black triangle in Figure 4c). This is clearly the case of a large elongated basin oriented obliquely near the fault termination which lies between the fault segments. Taking into consideration that in such cases the drainage networks follow the most active segment [1], the fault zone of Kandili seems to migrate north-westwards or it becomes more active to this direction-towards the Telethrion fault.

The distance of the central divide constitutes key geomorphic evidence, as it indicates limited footwall erosion at specific locations, which are the footwall of the Kandili fault and the uplifting blocks of the northwestern parts of the Telethrion and Dirfis faults. The drainage basins that drain these footwalls are young and small because of the neo-tectonic activity of the faults. On the contrary, the catchments of the back tilted drainage networks are older and more extensive.

From the maps of the spatial distribution of each one of the six calculated morphometric parameters (including Irta) (Figures 3 and 4), as well as from the catchments of the drainage networks flowing to the north (classified as of low relative tectonic activity-with only a few exceptions), there are no signs of the existence of the W-E fault along the Straits of Oreos-Trikeri reported by other studies $[27,28]$. This can be additionally confirmed by the fact that these basins are back-tilted and do not show geomorphological evidence of uplift. This low activity characterizing the area immediately south of the Oreos-Trikeri straits can be related to the fact that most of the extensional strain across the north Gulf of Evia is accommodated by the Arkitsa normal fault according to the findings of Chousianitis et al. [35]. This means that the expected significant strain accommodation along the normal faults on the northern side of the north Gulf of Evia does not exist. On the contrary, many drainage basins that lie on the footwall of the probable extension of the major Dirfis fault zone to the north show a moderate activity at least at the northern part. This possibly suggests the activity of the minor increased in number local faults at the NE part of the study area; although in some cases the geomorphic characteristics of the basins in this area are related to the lithology of the geological formations.

It is worth mentioning the presence of uplifted marine notches along the coastline of the areas that have been identified as of moderate to high relative tectonic activity by the calculated new index Irta. The locations of the uplifted marine notches are marked with asterisks in Figure $4 \mathrm{c}$ following Stiros et al. [37]. The accordance of recent coastal uplift with the results of Irta confirms the existence of the north-westward extension of the Dirfis fault zone. Furthermore, the Dirfis fault seems to be older than the other fault zones of the study area.

The results of the present study regarding the spatial distribution of relative tectonic activity are in good agreement with the results of the geomorphometric study of 36 coastal fans along the west coast of the north part of the Island [39]. The geographical distribution of the fan-catchment groups is controlled by variations in the relative tectonic uplift, which was the main control on the accommodation space for the development of the fans. The smaller and steeper, debris-flow dominated, coastal fans correspond to areas mapped as of high relative tectonic activity based on the results of Irta, 
whereas larger, fluvial-dominated fans, of gentle slope formed at areas that are characterized as of low relative tectonic activity.

Because no large magnitude earthquake has occurred in the Evia Island during instrumental times, the study of earthquake swarms in combination with the location of the faults is very important. Benetatos et al. [52] and Roumelioti and Kiratzi [53] showed that an N-S extension field (normal faulting) prevails in central Evia (north of Chalkis) as well as in NE Evia (to the north of the northern termination of the Dirfis fault zone). Two predominant fault directions have been identified, one ENE-WSW and a NW-SE (with a few strike slip mechanisms), following the topographic relief and the west coastline. The NW-SE trending Kandili fault is associated with drainage basins being classified as of high relative tectonic activity and, thus, it seems to strongly affect the landscape. Additionally, the WNW-ESE trending Telethrion fault zone, which, according to Sakellariou et al. [30], is capable of hosting strong earthquakes, seems to be responsible for the high relative tectonic activity as inferred from the Irta values of the footwall catchments. Most part of the fault systems of the north Evia Gulf are confirmed by seismic reflection surveys carried out in the area [54].

The lithology of the bedrock does not seem to be completely independent from the results. Drainage basins composed mostly of Triassic-Jurassic carbonate rocks seem to be controlled by the high relative fault activity, while basins mostly consisting of terrains that are less resistant to erosion show low tectonic activity according to the values of the morphometric parameters estimated in this study. However, the complexity of the bedrock in most of the drainage basins makes the correlation among lithology and morphometric characteristics of the basins difficult.

\section{Conclusions}

The calculation of geomorphic parameters can reveal indications of tectonic influence on the evolution of the landscape. The morphometric analysis of 189 drainage basins of the north part of the Evia Island, in central Greece, has shown that individual indices, such as Drainage Basin Slope $\left(\mathrm{S}_{\mathrm{b}}\right)$, Hypsometric Integral $\left(\mathrm{H}_{\mathrm{i}}\right)$, Asymmetry Factor $\left(\mathrm{A}_{\mathrm{f}}\right)$, Relief Ratio $\left(\mathrm{R}_{\mathrm{h}}\right)$, and Melton's Ruggedness Number $(\mathrm{M})$, can provide important information and that the indices co-evaluation through an integrated index (named Index of relative tectonic activity-Irta) can give meaningful results about the relative tectonic activity. The drainage basins were classified into three classes and based on this classification the study area was categorized into sub-areas of low, moderate, and high relative tectonic activity. About $68 \%$ of the study area is classified as of low, around $23 \%$ as of moderate and $9 \%$ as of high tectonic activity. The spatial distribution of the values of this new index seems to reflect the tectonic pattern of the study area. The basins of the drainage systems that drain the footwalls of Telethrion, Kandili, Aidipsos, and Dirfis faults show high values of the estimated morphometric indices as compared to the other basins.

This approach showed that the tectonic influence on the drainage systems of the north part of the Evia Island was demonstrated by the calculated parameters and that the morphometry of the drainage basins developed on the uplifting block of the major faults is indicative of tectonic activity. The morphometry of specific basins was also useful in mapping the fault segments' terminations. The geographic distribution of the morphometric indices is in good agreement with the hypothesis that the area between the segments of the Kandili and the Telethrion fault zone is inactive. The existence of an active fault along the straits of Oreos-Trikeri that was reported by previous studies was not confirmed by the morphometric analysis carried out within this research.

The analysis as a whole, i.e., the selection of the parameters and the categorization of the drainage basins, reflects the local conditions and, thus, it must be noted that the methodological approach and the classification of the relative tectonic activity show only relative differences and at a local level. 
Author Contributions: Selection of the morphometric parameters, K.V., E.K., D.P. and K.G.-P.; spatial GIS geo-database design and implementation, K.V. and C.C.; data curation, K.V., E.K., D.P., C.C. and K.G.-P.; analysis of the results, K.V., E.K., D.P., M.S. and K.G.-P.; visualization of the spatial distribution of the morphometric values, K.V. and C.C.; writing, review and editing—original draft preparation, K.V., E.K., D.P., M.S., C.C., K.G.-P. All authors have read and agreed to the published version of the manuscript.

Funding: This research received no external funding.

Acknowledgments: We would like to thank Athanassios Ganas for his constructive comments on an early version of the manuscript as well as the Editors of the Journal and the anonymous reviewers for their suggestions and corrections that significantly improved the paper.

Conflicts of Interest: The authors declare no conflict of interest.

\section{References}

1. Burbank, D.W.; Anderson, R.S. Tectonic Geomorphology, 2nd ed.; Wiley-Blackwell: Hoboken, NJ, USA, $2012 ;$ p. 460.

2. Keller, E.A.; Pinter, N. Active Tectonics, Earthquake, Uplift and Landscape, 2nd ed.; Prentice Hall: Upper Saddle River, NJ, USA, 2002; p. 362.

3. Karymbalis, E.; Papanastassiou, D.; Gaki-Papanastassiou, K.; Ferentinou, M.; Chalkias, C. Late Quaternary rates of stream incision in Northeast Peloponnese, Greece. Front. Earth Sci. 2016, 10, 455-478. [CrossRef]

4. Vassilakis, E.; Skourtsos, E.; Kranis, H. Tectonic uplift rate estimation with the quantification of morphometric indices. In Proceedings of the 8th Panhellenic Geographical Congress, Athens, Greece, 4-7 October 2007; pp. 17-26.

5. Goldsworthy, M.; Jackson, J. Active normal fault evolution in Greece revealed by geomorphology and drainage patterns. J. Geol. Soc. 2000, 157, 967-981. [CrossRef]

6. Karymbalis, E.; Ferentinou, M.; Giles, P. Use of morphometric variables and self-organizing maps to identify clusters of alluvial fans and catchments in the north Peloponnese, Greece. In Geology and Geomorphology of Alluvial and Fluvial Fans: Terrestrial and Planetary Perspectives; Ventra, D., Clarke, L.E., Eds.; Geological Society, Special Publications: London, UK, 2018; Volume 440, pp. 45-64. [CrossRef]

7. El Hamdouni, R.; Irigaray, C.; Fernández, T.; Chacón, J.; Keller, E.A. Assessment of relative active tectonics, southwest border of the Sierra Nevada (southern Spain). Geomorphology 2008, 96, 150-173. [CrossRef]

8. Maroukian, H.; Gaki-Papanastassiou, K.; Karymbalis, E.; Vouvalidis, K.; Pavlopoulos, K.; Papanastassiou, D.; Albanakis, K. Morphotectonic control on drainage network evolution in the Perachora Peninsula, Greece. Geomorphology 2008, 102, 81-92. [CrossRef]

9. Siddiqui, A.; Soldati, M. Appraisal of active tectonics using DEM-based hypsometric integral and trend surface analysis in Emilia-Romagna Apennines, northern Italy. Turk. J. Earth Sci. 2014, 23, 277-292. [CrossRef]

10. Dehbozorgi, M.; Pourkermani, M.; Arian, M.; Matkan, A.A.; Motamedi, H.; Hosseiniasl, A. Quantitative analysis of relative tectonic activity in the Sarvestan area, central Zagros, Iran. Geomorphology 2010, 121, 329-341. [CrossRef]

11. Dar, R.A.; Romshoo, S.A.; Chandra, R.; Ahmad, I. Tectono-geomorphic study of the Karewa Basin of Kashmir Vally. J. Asian Earth Sci. 2014, 92, 143-156. [CrossRef]

12. Ghosh, S.; Sivakumar, R. Assessment of morphometric parameters for the development of Relative Active Tectonic Index and its significant for seismic hazard study: An integrated geoinformatic approach. Environ. Earth Sci. 2018, 77, 600. [CrossRef]

13. Partabian, A.; Nourbakhsh, A.; Ameri, S. GIS-based evaluation of geomorphic response to tectonic activity in Makran Mountain Range, SE of Iran. Geosci. J. 2016, 20, 921-934. [CrossRef]

14. Ntokos, D.; Lykoudi, E.; Rondoyanni, T. Geomorphic analysis in areas of low-rate neotectonic deformation: South Epirus (Greece) as a case study. Geomorphology 2016, 263, 156-169. [CrossRef]

15. Siddiqui, S.; Castaldini, D.; Soldati, M. DEM-based drainage network analysis using steepness and Hack SL indices to identify areas of differential uplift in Emilia-Romagna Apennines, northern Italy. Arab. J. Geosci. 2017, 10, 3. [CrossRef]

16. Mahmood, A.A.; Cloaguen, R. Appraisal of active tectonics in Hindu Kush: Insights from DEM derived geomorphic indices and drainage analysis. Geosci. Front. 2012, 3, 407-428. [CrossRef]

17. Arian, A.; Aram, Z. Relative tectonic activity classification in the Kermanshah area, western Iran. Solid Earth 2014, 5, 1277-1291. [CrossRef] 
18. Anand, A.K.; Pradhan, S.P. Assessment of active tectonics from geomorphic indices and morphometric parameters in part of Ganga basin. J. Mt. Sci. 2019, 16, 1943-1961. [CrossRef]

19. Goldsworthy, M.; Jackson, J.; Haines, J. The continuity of active fault systems in Greece. Geophys. J. Int. 2002, 148, 596-618. [CrossRef]

20. Kiratzi, A. Stress tensor inversions along the westernmost North Anatolian Fault Zone and its continuation into the North Aegean Sea. Geophys. J. Int. 2002, 151, 360-376. [CrossRef]

21. Genre, C. Cartes des Lineaments Structuraux Établies à Partir d'Images Landsat II et des Données Sismotectoniques OASP et IGME. Rapport de Recherche; CIEM: Poitiers, France, 1985.

22. Roberts, S.; Jackson, J. Active normal faulting in central Greece: An overview. In The Geometry of Normal Faults; Roberts, A.M., Yielding, G., Freeman, B., Eds.; Geological Society, Special Publications: London, UK, 1991; Volume 56, pp. 125-142. [CrossRef]

23. Mettos, A.; Rontogianni, T.; Papadakis, G.; Paschos, P.; Georgiou, C. New data on the geology of the Neogene deposits of the North Euboea. Bull. Geol. Soc. Greece 1991, 25, 71-83.

24. Gautier, P. Géométrie Crustale et Cinématique de l'Extension Tardi-Orogénique dans le Domaine Centre-Égéen (Iles des Cyclades et d'Eubée, Grèce). Ph.D. Thesis, Géosciences Rennes, Université de Rennes, Rennes, France, 1995.

25. Genre, C. Néotectonique et développement des terrasses de l'Holocène récent: L'exemple de l'Eubée (Grèce centreorientale)/Neotectonics and Late Holocene terraces. The example of Euboea (Central Eastern Greece). Géomorphologie 1999, 5, 143-158. [CrossRef]

26. Popovic, A. Analyse Morphostructurale sur un Exemple de Bloc Basculé d'Échelle Crustale (l'Île d' Eubée, Grèce) dans Une Région d'Extension Active (Grèce Centrale); Mémoire de DEA Géosciences Rennes, Tectonique: Rennes, France, 1996; p. 12.

27. Galanakis, D.; Pavlides, S.; Mountrakis, D. Recent brittle tectonics in Almyros-Pagasitikos, Maliakos, N. Euboea and Pilion. Bull. Geol. Soc. Greece 1998, 32, 263-273.

28. Palyvos, N.; Bantekas, I.; Kranis, H. Transverse fault zones of subtle geomorphic signature in northern Evia island (central Greece extensional province): An introduction to the Quaternary Nileas graben. Geomorphology 2006, 76, 363-374. [CrossRef]

29. Ganas, A.; Oikonomou, I.A.; Tsimi, C. NOAfaults: A digital database for active faults in Greece. Bull. Geol. Soc. Greece 2013, 47, 518-530. [CrossRef]

30. Sakellariou, D.; Rousakis, G.; Kaberi, H.; Kapsimalis, V.; Georgiou, P.; Kanellopoulos, T.; Lykousis, V. Tectono-sedimentary structure and Late Quaternary evolution of the North Evia Gulf basin, central Greece: Preliminary results. Bull. Geol. Soc. Greece 2007, 40, 451-462. [CrossRef]

31. Institute of Geology and Mineral Exploration of Greece (IGME), Geological Map of Greece 1:50,000. Sheets: Steni-Dhirfios, Psachna-Pilion, Pelasgia-Myli, Limni, Larimna, Kimi, Istiaia; IGME: Athens, Greece, 1981.

32. Mountrakis, D.M. Geology of Greece; University Studio Press: Thessaloniki, Greece, 1985; p. 207. (In Greek)

33. Institute of Geology and Mineral Exploration of Greece (IGME). Geotechnical Map of Greece, Scale 1:500,000; IGME: Athens, Greece, 1993.

34. Ganas, A.; Papoulia, I. High-resolution, Digital Mapping of the Seismic Hazard within the Gulf of Evia Rift, Central Greece Using Normal Fault Segments as Line Sources. Nat. Hazards 2000, 22, 203-223. [CrossRef]

35. Chousianitis, K.; Ganas, A.; Gianniou, M. Kinematic interpretation of present-day crustal deformation in central Greece from continuous GPS measurements. J. Geodyn. 2013, 71, 1-13. [CrossRef]

36. Kranis, H. Neotectonic basin evolution in central-eastern mainland Greece: An overview. Bull. Geol. Soc. Greece 2007, 40, 360-373. [CrossRef]

37. Stiros, S.C.; Arnold, M.; Pirazzoli, P.A.; Laborel, J.; Laborel, F.; Papageorgiou, S. Historical cosesmic uplift on Euboea island, Greece. Earth Planet Sci. Lett. 1992, 108, 109-117. [CrossRef]

38. Evelpidou, N.; Vassilopoulos, A.; Pirazzoli, P.A. Holocene emergence in Euboea island (Greece). Mar. Geol. 2012, 295-298, 14-19. [CrossRef]

39. Valkanou, K.; Karymbalis, E.; Papanastassiou, D.; Gaki-Papanastassiou, K.; Giles, P. Analysis of relationships among coastal alluvial fans and their contributing catchments in North Evoikos Gulf (Central Greece). Bull. Geol. Soc. Greece 2013, 47, 344-355. [CrossRef]

40. Pantosti, D.; De Martini, P.M.; Papanastassiou, D.; Lemeille, F.; Palyvos, N.; Stavrakakis, G. Paleoseismological trenching across the Atalanti fault (Central Greece): Evidence for the ancestors of the 1894 earthquake during Middle Age and Roman time. Bull. Seismol. Soc. Am. 2004, 94, 531-549. [CrossRef] 
41. Papanastassiou, D.; Latoussakis, J.; Stavrakakis, G. A revised catalogue of earthquakes in the broader area of Greece for the period 1950-2000. Bull. Geol. Soc. Greece 2001, 34, 1563-1566. [CrossRef]

42. Strahler, A.N. Hypsometric (area-altitude) analysis of erosional topography. Geol. Soc. Am. Bull. 1952, 63, 1117-1142. [CrossRef]

43. Pike, R.J.; Wilson, S.E. Elevation-Relief Ratio, Hypsometric Integral, and Geomorphic Area-Altitude Analysis. Geol. Soc. Am. Bull. 1971, 82, 1079-1084. [CrossRef]

44. Mayer, L. Introduction to Quantitative Geomorphology: An Exercise Manual; Prentice Hall: Englewood Cliffs, NJ, USA, 1990; p. 384.

45. Pavlides, S.V. Earthquake Geology; University Studio Press: Thessaloniki, Greece, 2003; p. 378. (In Greek)

46. Schumm, S.A. Evolution of drainage systems and slopes in badlands at Perth Amboy, New Jersey. Geol. Soc. Am. Bull. 1956, 67, 597-646. [CrossRef]

47. Ritter, D.F.; Kochel, R.C.; Miller, J.R. Process Geomorphology, 3rd ed.; W.C. Brown Publishers: Dubuque, IA, USA, 1995; p. 539.

48. Panek, T. The use of morphometric parameters in tectonic geomorphology (on the example of the Western Beskydy Mts). Geograph. Acta Univ. Carol. 2004, 1, 111-126.

49. Melton, M.A. The geomorphic and palaeoclimatic significance of alluvial deposits in Southern Arizona. J. Geol. 1965, 73, 1-38. [CrossRef]

50. Marinos, P.; Hoek, E. GSI: A geologically friendly tool for rock mass strength estimation. In Proceedings of the GeoEng 2000, Melbourne, Australia, 19-24 November 2000; pp. 1422-1442.

51. Leeder, M.R.; Jackson, J.A. The interaction between normal faulting and drainage in active extensional basins, with examples from the western United States and central Greece. Basin Res. 2007, 5, 79-102. [CrossRef]

52. Benetatos, C.; Kiratzi, A.; Kementzetzidou, K.; Roumelioti, Z.; Karakaisis, G.; Scordilis, E.; Latoussakis, I.; Drakatos, G. The Psachna (Evia Island) earthquake swarm of June 2003. Bull. Geol. Soc. Greece 2004, 36, 1379-1388. [CrossRef]

53. Roumelioti, Z.; Kiratzi, A. Moderate Magnitude Earthquake Sequences in Central Greece (for the year 2008). Bull. Geol. Soc. Greece 2010, 43, 2144-2153. [CrossRef]

54. Van Andel, T.H.; Perissoratis, C. Late Quaternary depositional history of the North Evvoikos Gulf, Aegean Sea, Greece. Mar. Geol. 2006, 232, 157-172. [CrossRef] 